\title{
Theory and Technology of the Phosphorus Extraction from Ferrophosphorus
}

\author{
Serzhanov Galimzhan Mendikarayevich ${ }^{1}$, Shevko Viktor Mikhaylovich ${ }^{1} \&$ Yeskendirova Marina Mikhaylovna ${ }^{1}$ \\ ${ }^{1}$ M. Auezov South Kazakhstan State University, Republic of Kazakhstan \\ Correspondence: Serzhanov Galimzhan Mendikarayevich, M. Auezov South Kazakhstan State University, \\ Republic of Kazakhstan.
}

Received: December 3, 2014

Accepted: December 9, 2014 Online Published: May 30, 2015

doi:10.5539/mas.v9n6p160

URL: http://dx.doi.org/10.5539/mas.v9n6p160

\begin{abstract}
This article contains the research results of thermodynamic modelling of the chemical interaction of iron phosphides $\left(\mathrm{Fe}_{3} \mathrm{P}, \mathrm{Fe}_{2} \mathrm{P}, \mathrm{FeP}\right.$ and $\left.\mathrm{FeP}_{2}\right)$ with ferrosilicon $\mathrm{FeSi}_{2}$. The results were received by a method of the full thermodynamic analysis using the program HSC-5.1 of the Finnish metallurgical company Outokumpu, which was developed on a principle of the Gibbs energy minimization. The article considers the experimental results concerning to kinetics of the phosphorus extraction from electrothermal ferrophosphorus using ferrosilicon of a grade FS65. In addition, optimum technological parameters of the phosphorus extraction from the industrial ferrophosphorus, containing $26,4 \%$ of phosphorus, and manufacture of a ferroalloy were determined.
\end{abstract}

Keywords: iron phosphides, ferrophosphorus, iron silicides, thermodynamic modelling, kinetics, ferrosilicon, phosphorus

\section{Introduction}

At the electrothermal production of yellow phosphorus from a phosphorite, quartzite and coke mixture, 1 ton of the phosphorus produced gives to $300 \mathrm{~kg}$ of a by-product - ferrophosphorus (1). The basic consumer of ferrophosphorus is the ferrous metallurgy, in which ferrophosphorus is used for melting of alloyed phosphorus-containing steels (for example, automatic steels), and iron casting. However, despite the introduction of (2) on industrial enterprises, a firm demand on the electrothermal ferrophosphorus has decreased recently because of chemical heterogeneity of the ferrophosphorus concerning to $\mathrm{P}, \mathrm{Mn}, \mathrm{Si}$ and the presence of slag inclusions in it (3). In connection with this, there is a necessity of development of a rational method of the electrothermal ferrophosphorus processing for manufacturing markeTable products. The uniqueness of ferrophosphorus (as a raw material) is connected with a high phosphorus content - in 2-2,5 times more than in phosphorites.

In the world practice there are several directions of the ferrophosphorus processing (3-14). However, known methods of the ferrophosphorus processing have essential technological and economic disadvantages. So, phosphatic slags produced from ferrophosphorus are characterized by insufficient agrochemical activity, poor solubility in water owing to the presence of phosphorus in acid-soluble or citrate-soluble forms, therefore they have a limited application field. The technology of alkaline metals phosphates is much more complex, than the phosphatic slag technology, and a cost price of the products is higher. At the ferrophosphorus chlorination there are the problems concerning to the phosphorus chlorides purification from $\mathrm{Si}$, Ti, V. Methods of the ferrophosphorus processing with production of $\mathrm{P}_{2} \mathrm{O}_{5}$ and phosphoric acid (processing by water steam, nitric acid, sulfuric acid, quartzite) are characterized by the nitrogen (II) oxide liberation, a low efficiency of sulfuric acid, a necessity of high pressure application, collateral formation of $\mathrm{SO}_{2}$, a low degree of the phosphorus conversion in $\mathrm{P}_{2} \mathrm{O}_{5}$. The obtaining $\mathrm{P}_{2} \mathrm{O}_{3}$ from ferrophosphorus is complicated by the iron phosphate formation. The manufacture of element phosphorus and ferrosilicon from ferrophosphorus is characterized by a high power consumption connected with a necessity of preliminary reduction of $\mathrm{Si}$ from $\mathrm{SiO}_{2}$ by carbon or with using the expensive technical silicon. The ferrophosphorus processing on phosphorus pentasulphide with further production of orthophosphoric acid is a multiphase manufacture demanding the cleaning phosphorus pentasulphide and leading to nonutilizable wastes and additional power inputs. The heating ferrophosphorus in vacuum even at $1600-1650{ }^{\circ} \mathrm{C}$ and low residual pressure allow taking the phosphorus no more $75 \%$. The ferrophosphorus processing in the presence of aluminium passes not up to the end and is accompanied by 
formation of an intermediate $\mathrm{Fe}_{3} \mathrm{P}$, in addition, at the hydrolysis of AlP a poisonous phosphine is liberated.

At the development of a rational way of the ferrophosphorus processing we chose as a basis the ability of silicon to displace phosphorus from an iron phosphide melt. The given article contains the research results in the field of theory and technology of phosphorus extraction from iron phosphides and industrial ferrophosphorus in the presence of $\mathrm{FeSi}_{2}$ and ferrosilicon of the grade FS65.

\section{Research Method}

Thermodynamic research of the chemical interaction of iron phosphides with ferrosilicon was carried out using the program HSC-5.1 of the Finnish metallurgical company Outokumpu, which was developed on a principle of the Gibbs energy minimization $(15,16)$. The program database contains the information about 17000 substances. The program HSC Chemistry used in the given work is based on ideology of the European consortium SGTE (Scientific Group Thermodata Europe), which occupies with the development, support and distribution of high-quality databases. The SGTE structure includes specialized scientific centers in Germany, Canada, France, Sweden, the Great Britain and the USA (17). The subprogram "Eguilibrium Compositions" is applied for the calculation of an equilibrium degree of elements' distribution in the investigated systems.

Kinetic research of the phosphorus extraction from ferrophosphorus at the presence of ferrosilicon was performed using an induction heating apparatus. An initial charge (100-110 g) was placed in a graphite crucible, which was put into the furnace and kept in a melting space of the furnace necessary time. Temperature in the furnace was measured by an optical pyrometer and a tungsten-rhenium thermocouple. After the experiment termination the crucible was taken from the furnace. A melt cooled in the crucible was weighed and analyzed on a phosphorus content using the technique (2). Some samples were analyzed using a scanning electron microscope JSM-6490LM (Japan), and also an X-ray diffractometer D8 Advance (Bruker). A degree of the phosphorus liberation in a gas phase $\left(\alpha_{\mathrm{P}}, \%\right)$ was calculated according to the results of the chemical analysis of the ferrophosphorus and the melt on a phosphorus content using the following equation:

$$
\alpha_{\mathrm{P}}=\frac{G_{F P} \cdot C_{\mathrm{P}(F P)}-G_{m e l t} \cdot \mathrm{C}_{\mathrm{P}(m e l t)}}{G_{F P} \cdot \mathrm{C}_{\mathrm{P}(F P)}} \cdot 100 ;
$$

where $G_{F P}$ and $G_{m e l t}$ - masses of the ferrophosphorus used and the melt produced accordingly, g;

$\mathrm{C}_{\mathrm{P}(F P)}$ and $\mathrm{C}_{\mathrm{P}(m e l t)}$ - a phosphorus content in the initial ferrophosphorus and in the melt accordingly, parts of unity.

At the experiment carrying out the electrothermal ferrophosphorus of the grade FeP 20-6 of the Limited Partnership "Kazphosphate" (Kazakhstan) was used, which has the following chemical composition: 26,4 \% of P, $1,3 \%$ of Si, $4,5 \%$ of Mn, $66,0 \%$ of Fe, $1,8 \%$ - other, and also the ferrosilicon of the grade FS 65 (18) with the following composition: $63,8 \%$ of Si, $0,6 \%$ of Mn, $1,1 \%$ of $\mathrm{Al}, 33,1 \%$ of $\mathrm{Fe}$, other $-1,4 \%$. The experimental data were processed using the equation:

$$
\alpha=1-\exp \left[-k^{*} \tau^{n}\right],
$$

where $\mathrm{k}$ and $\mathrm{n}$ - empirical coefficients, $\tau$ - duration of the process, minutes, $\alpha$ - degree of realization of the process, parts of unity. A speed of the process (V) (according to the IUPAC recommendations (20) as a speed of changing a degree of realization of a process,) was determined on the basis of the formula $V=d \alpha / d \tau$. In our case, a speed of the phosphorus liberation from the ferrophosphorus was calculated by means of differentiation of the equation (2) (21):

$$
V=\frac{\mathrm{d} \alpha}{\mathrm{d} \tau}=\mathrm{n} \cdot \mathrm{k}^{1 / \mathrm{n}} \cdot\left[-\ln (1-\alpha)^{1-\frac{1}{n}}\right] \cdot(1-\alpha) .
$$

The equation (7) allows us to estimate $V$ for every value of $\alpha_{p}$ if " $n$ " and "k" are known.

For the calculation of apparent activation energy of the process $\left(\mathrm{E}_{\mathrm{ap}}\right)$ according to (22-23) we determined the dependence $\operatorname{lgV}=\mathrm{f}\left({ }^{1} / \mathrm{T}\right)$ for fixed values $\alpha_{\mathrm{p}}$. Then $\mathrm{E}_{\mathrm{ap}}$ was estimated under the formula:

$$
E_{a p}=2,303 * 8,314 *|\operatorname{tg} \varphi|
$$

where $\varphi$ - inclination of the line to the abscissa axis; 8,314 - the universal gas constant, $\mathrm{J} /\left(\right.$ mole* $\left.^{*}\right)$; $\mathrm{E}_{\mathrm{ap}}-$ apparent activation energy, $\mathrm{J} / \mathrm{mole}$.

Optimum technological parameters were determined by means of the fulfillment of the researches using the method of rotoTable planning of a second-order experiment, the development of adequate regression equation and the graphic optimization of the process by use of horizontal sections of the response surfaces (22) 


\section{Results and Their Discussion}

\subsection{Thermodynamic Analysis}

For the system $\mathrm{Fe}_{3} \mathrm{P}-3 \mathrm{FeSi}_{2}$ (the predicted reaction $\mathrm{Fe}_{3} \mathrm{P}+3 \mathrm{FeSi}_{2}=6 \mathrm{FeSi}+0,5 \mathrm{P}_{2}$ ) in a temperature interval of $500-2000^{\circ} \mathrm{C}$ the basic substances are $\mathrm{FeP}_{2}, \mathrm{FeP}, \mathrm{Fe}_{3} \mathrm{P}, \mathrm{P}_{4}, \mathrm{P}_{2}, \mathrm{FeSi}, \mathrm{FeSi}_{2}, \mathrm{Fe}_{5} \mathrm{Si}_{3}$ (Figure 1). In the system at $500^{\circ} \mathrm{C} 78 \%$ of phosphorus transit in $\mathrm{FeP}_{2}, 21,3 \%$ - in $\mathrm{FeP}$, the rest $0,7 \%$ passes in $\mathrm{Fe}_{3} \mathrm{P}$. Thus the silicon is distributed in the following way: 79,4 \% - in $\mathrm{FeSi}$, and 20,6 \% remain in $\mathrm{FeSi}_{2}$.

The beginning (1\%) of the formation of a gaseous phosphorus as $\mathrm{P}_{4}$ and $\mathrm{P}_{2}$ in the system is observed at $1110^{\circ} \mathrm{C}$. The transformation of all the phosphorus in the gaseous $\mathrm{P}_{2}, \mathrm{P}_{4}\left(\alpha_{\mathrm{P}(\mathrm{gas})}\right)$ takes place at $1800^{\circ} \mathrm{C}$ (at $1700^{\circ} \mathrm{C} \alpha_{\mathrm{P}(\mathrm{gas})}$ makes $96,7 \%$ ). Most probably, the observed formation of $\mathrm{FeP}_{2}$ and $\mathrm{FeP}$ in the system $\mathrm{Fe}_{3} \mathrm{P}-3 \mathrm{FeSi}_{2}$ is connected with the reactions:

$$
\begin{gathered}
2 \mathrm{Fe}_{3} \mathrm{P}+5 \mathrm{FeSi}_{2}=10 \mathrm{FeSi}+\mathrm{FeP}_{2} \\
\mathrm{Fe}_{3} \mathrm{P}+2 \mathrm{FeSi}_{2}=4 \mathrm{FeSi}+\mathrm{FeP}
\end{gathered}
$$

On the basis of the $\Delta \mathrm{G}_{\mathrm{T}}{ }^{0}$ calculation these reactions are possible at $\mathrm{T} \geq 500^{0} \mathrm{C}$ (Table 1).

Table 1. Temperature effect on $\Delta \mathrm{G}_{\mathrm{T}}{ }^{0}\left(\mathrm{~kJ} / \mathrm{mol}\right.$ of $\left.\mathrm{Fe}_{3} \mathrm{P}\right)$ of $\mathrm{FeP}_{2}$ and $\mathrm{FeP}$ formation from $\mathrm{Fe}_{2} \mathrm{P}$

\begin{tabular}{cccccc}
\hline Reaction & \multicolumn{5}{c}{ Temperature, ${ }^{0} \mathrm{C}$} \\
\cline { 2 - 6 } & 500 & 700 & 900 & 1100 & 1300 \\
\hline 5 & $-14,11$ & $-14,88$ & $-15,80$ & $-16,91$ & $-18,26$ \\
6 & $-11,36$ & $-12,01$ & $-12,84$ & $-13,91$ & $-15,29$ \\
\hline
\end{tabular}

Then, on the second stage the $\mathrm{FeP}_{2}$ and $\mathrm{FeP}$ formed react with $\mathrm{FeSi}_{2}$ :

$$
\begin{gathered}
\mathrm{FeP}_{2}+\mathrm{FeSi}_{2}=2 \mathrm{FeSi}+\mathrm{P}_{2} \\
\mathrm{FeP}+\mathrm{FeSi}_{2}=2 \mathrm{FeSi}+0,5 \mathrm{P}_{2}
\end{gathered}
$$

For these reactions temperatures of the beginning are $1252^{\circ} \mathrm{C}$ and $1122^{\circ} \mathrm{C}$ accordingly.

Summarily the reactions 5-8 lead to the reaction:

$$
3 \mathrm{Fe}_{2} \mathrm{P}+6 \mathrm{FeSi}_{2}=12 \mathrm{FeSi}+1,5 \mathrm{P}_{2},\left(\mathrm{Fe}_{3} \mathrm{P}+3 \mathrm{FeSi}_{2}=6 \mathrm{FeSi}+0,5 \mathrm{P}_{2}\right) \text {. }
$$

Thereby the chemical conversion in the system (concerning the phosphorus) occurs under the scheme:

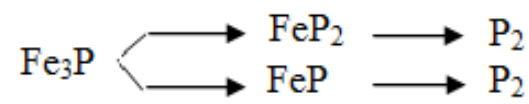

In the system $\mathrm{Fe}_{2} \underline{\mathrm{P}}-2 \mathrm{FeSi}_{2}$ (the predicted reaction $\mathrm{Fe}_{2} \mathrm{P}+2 \mathrm{FeSi}_{2}=4 \mathrm{FeSi}+0,5 \mathrm{P}_{2}$ ) temperature of the beginning $(1 \%)$ of the gaseous phosphorus formation decreases from $1110^{\circ} \mathrm{C}$ to $1089^{\circ} \mathrm{C}$. Formation of $\mathrm{FeP}$ and $\mathrm{Fe}_{2} \mathrm{P}$ in the given system is a result of the reactions:

$$
\begin{gathered}
\mathrm{Fe}_{2} \mathrm{P}+\mathrm{FeSi}_{2}=\mathrm{FeP}+2 \mathrm{FeSi} ; \\
2 \mathrm{Fe}_{2} \mathrm{P}+3 \mathrm{FeSi}_{2}=\mathrm{FeP}_{2}+6 \mathrm{FeSi} .
\end{gathered}
$$

So, $\Delta \mathrm{G}_{\mathrm{r}}{ }^{0}$ of the reaction (11) at $500^{\circ} \mathrm{C}$ makes $-11,91 \mathrm{~kJ} / \mathrm{mol}$ of $\mathrm{Fe}_{2} \mathrm{P}$, at $900^{\circ} \mathrm{C}$ it makes $-13,28 \mathrm{~kJ} / \mathrm{mol}_{\text {of }} \mathrm{Fe}_{2} \mathrm{P}$, and $\Delta \mathrm{G}_{\mathrm{T}}{ }^{0}$ for the reaction (12) is $-122 \mathrm{~kJ} / \mathrm{mol}$ of $\mathrm{Fe}_{2} \mathrm{P}$ and $-13,8 \mathrm{~kJ} / \mathrm{mol}$ of $\mathrm{Fe}_{2} \mathrm{P}$ accordingly. Then, at the temperature above $1089^{\circ} \mathrm{C}$ there is the formation of $\mathrm{P}_{2}$ owing to the reactions $(7,8)$. Conversion of all the phosphorus in a gaseous condition takes place at $1800^{\circ} \mathrm{C}$ (Figure 1). That is the phosphorus conversion in the system occurs according to the scheme:

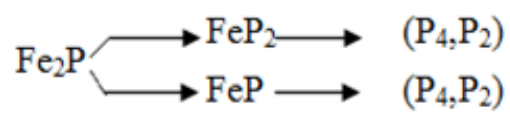

In the system $\mathrm{FeP}-\mathrm{FeSi}_{2}$ (the predicted reaction $\mathrm{FeP}+\mathrm{FeSi}_{2}=2 \mathrm{FeSi}+0,5 \mathrm{P}_{2}$ ) the formation of $\mathrm{FeP}_{2}$ and $\mathrm{FeSi}$ (Figure 2) is a consequence of the reaction:

$$
\mathrm{FeP}+\mathrm{FeSi}_{2}=\mathrm{FeP}_{2}+\mathrm{FeSi}
$$


On the basis of calculation of $\Delta \mathrm{G}_{\mathrm{T}}{ }_{\mathrm{T}}$ this reaction is possible already at $100^{\circ} \mathrm{C}$ (Table 2).

Table 2. Temperature effect on $\Delta \mathrm{G}_{\mathrm{T}}{ }^{0}(\mathrm{~kJ} / \mathrm{mol}$ of $\mathrm{FeP})$ of the reaction (14)

\begin{tabular}{ccccccccc}
\hline $\mathrm{T},{ }^{0} \mathrm{C}$ & 100 & 300 & 500 & 700 & 900 & 1000 & 1100 & 1300 \\
\hline$\Delta \mathrm{G}_{\mathrm{T}}{ }^{0}$ & $-2,435$ & $-2,598$ & $-2,748$ & $-2,871$ & $-2,953$ & $-2,978$ & $-2,951$ & $-2,991$ \\
\hline
\end{tabular}

In this system $1 \%$ of the $\mathrm{P}_{2}$ formation occurs at $1017^{\circ} \mathrm{C}$, and the full conversion - at $1800^{\circ} \mathrm{C}$ (at $1700^{\circ} \mathrm{C} \alpha_{\mathrm{Pr}}$ makes $98,5 \%$ ). A chemical reaction is the following:

$$
\mathrm{FeP} \rightarrow \mathrm{FeP}_{2} \rightarrow\left(\mathrm{P}_{4}, \mathrm{P}_{2}\right)
$$

For the system $\mathrm{FeP}_{2}-\mathrm{FeSi}_{2}$ (the predicted reaction $\mathrm{FeP}_{2}+\mathrm{FeSi}_{2}=2 \mathrm{FeSi}+\mathrm{P}_{2}$ ) a temperature of the $1 \%$ formation of the phosphorus is $519^{\circ} \mathrm{C}$, and transition of all the phosphorus in the gas phase takes place at $1800^{\circ} \mathrm{C}$ (Figure 2).

These researches allow us to define laws of the chemical interaction in the systems iron phosphides $-\mathrm{FeSi}_{2}$. So, a temperature of the $1 \%$ formation of the gaseous phosphorus (T1) depends on an atomic fraction of phosphorus in the iron phosphides $\left(\mathrm{P}_{\text {phos }}\right.$ ), decreasing from $1113^{\circ} \mathrm{C}$ to $519^{\circ} \mathrm{C}$ at increase $\mathrm{P}_{\text {phos }}$ from $25 \%$ to $66,67 \%$ (Table 3) according to the equation:

$$
\mathrm{T} 1=0,5166 \mathrm{P}_{\text {phos }}+65,501 .
$$



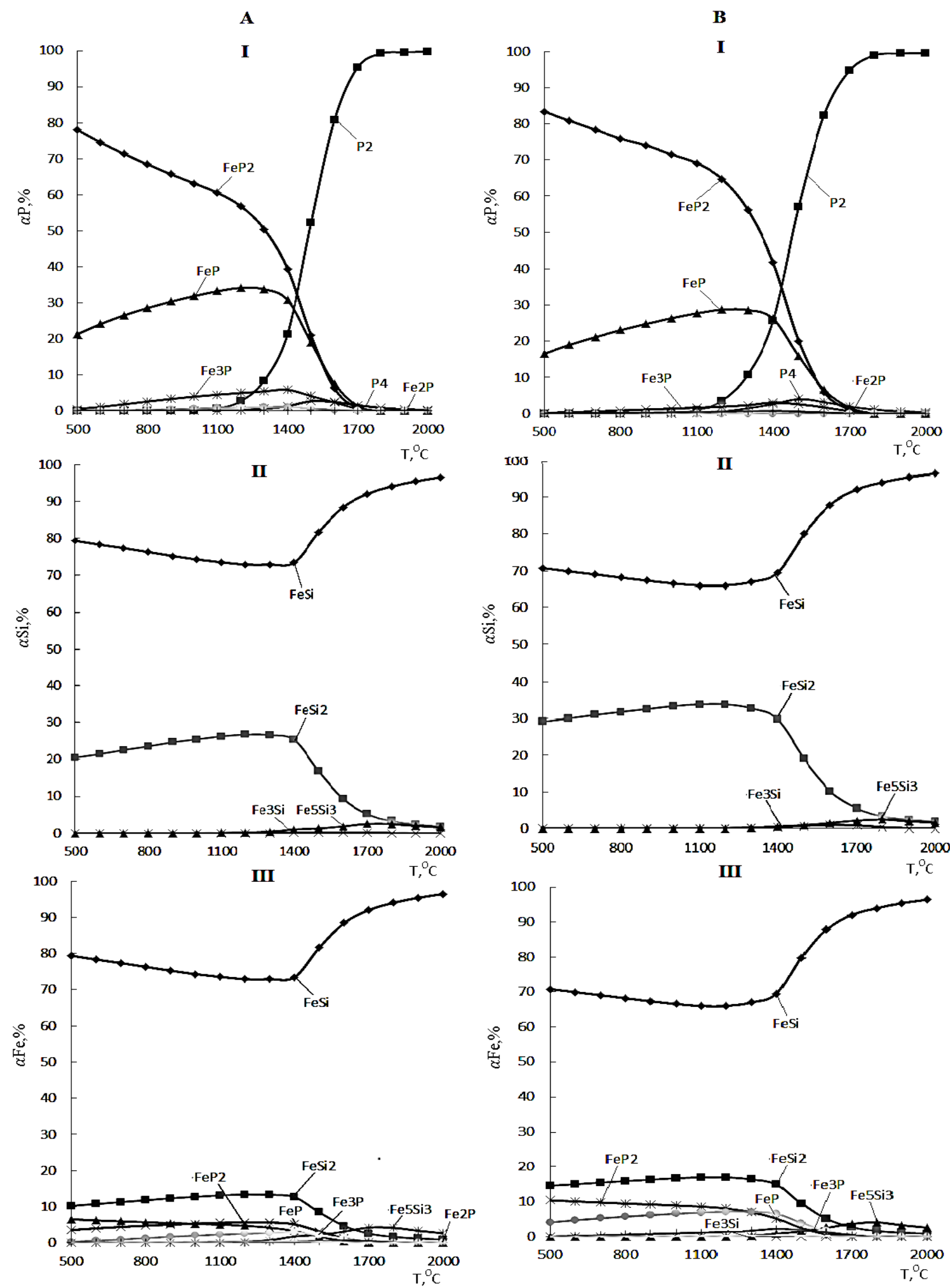

$\mathrm{A}$ - the system $\mathrm{Fe}_{3} \mathrm{P}-\mathrm{FeSi}_{2}, \mathrm{~B}$ - the system $\mathrm{Fe}_{2} \mathrm{P}-\mathrm{FeSi}_{2}, \mathrm{I}-\mathrm{P}, \mathrm{II}-\mathrm{Si}$, III $-\mathrm{Fe}$

Figure 1. Temperature effect on an equilibrium degree $(\alpha)$ of the $\mathrm{P}, \mathrm{Si}$ and $\mathrm{Fe}$ distribution in the systems $\mathrm{Fe}_{3} \mathrm{P}-$ $\mathrm{FeSi}_{2}, \mathrm{Fe}_{2} \mathrm{P}-\mathrm{FeSi}_{2}$ at pressure $0,1 \mathrm{MPa}$ 

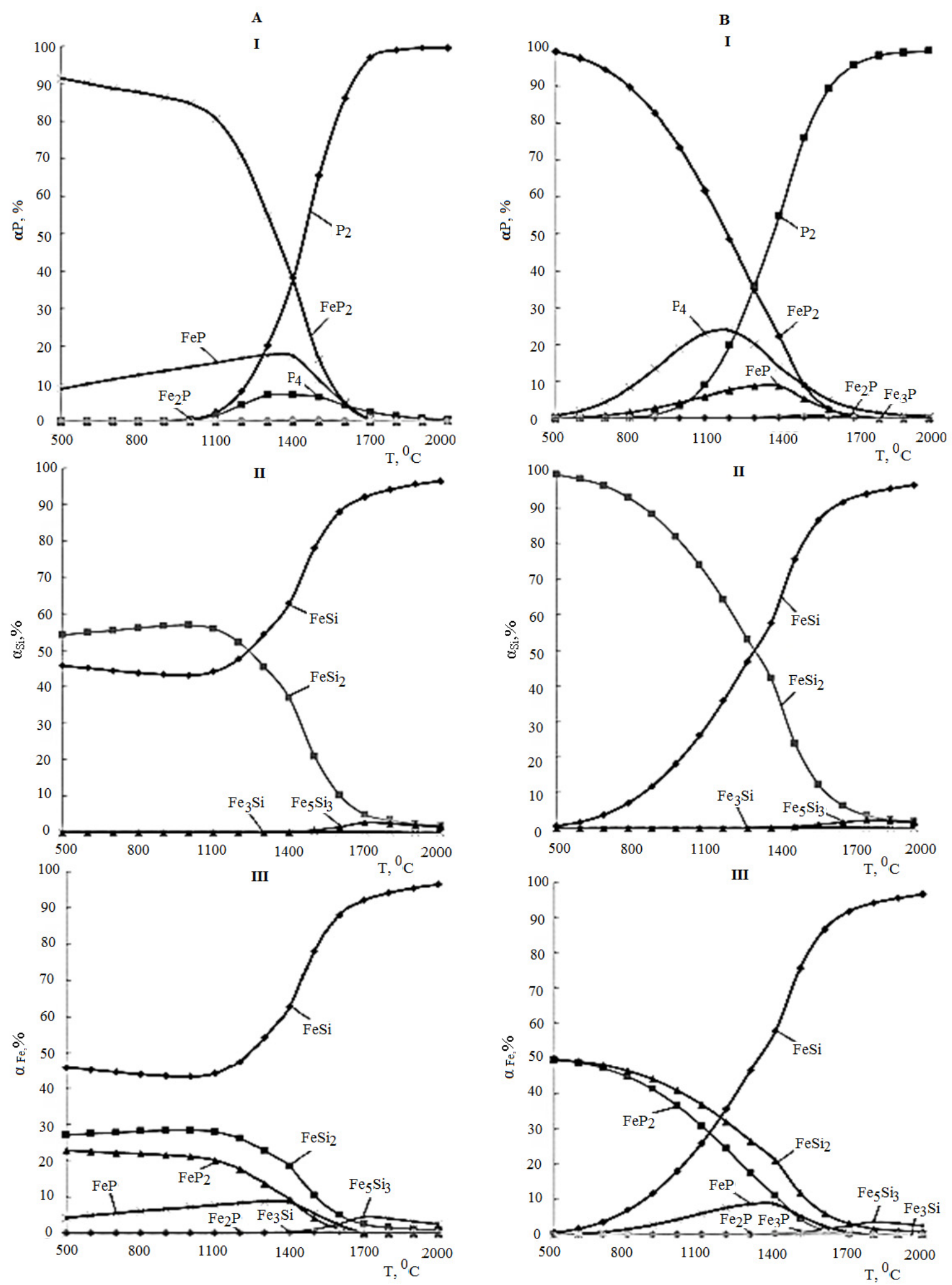

A - the system $\mathrm{FeP}-\mathrm{FeSi}_{2}$, B - the system $\mathrm{FeP}_{2}-\mathrm{FeSi}_{2}, \mathrm{I}-\mathrm{P}$, II - Si, III - Fe

Figure 2. Temperature effect on an equilibrium degree of $\mathrm{P}$, $\mathrm{Si}$ and $\mathrm{Fe}$ distribution in the systems $\mathrm{FeP}-\mathrm{FeSi}_{2}$, $\mathrm{FeP}_{2}-\mathrm{FeSi}_{2}$ at pressure $0,1 \mathrm{MPa}$ 
Increase of $\mathrm{P}_{\mathrm{phos}}$ also positively influences on $\alpha_{\mathrm{P}_{\Gamma}}$ at high temperatures (Table 3).

Table 3. Influence of a mole fraction of phosphorus in iron phosphide $\left(\mathrm{P}_{\mathrm{phos}}\right)$ on the temperature of $1 \%$ phosphorus formation (T1) and $\alpha_{\mathrm{P}_{\Gamma}}$

\begin{tabular}{ccccc}
\hline $\mathrm{P}_{\mathrm{phos}}, \%$ & 25,0 & 33,33 & 50,0 & 66,67 \\
\hline $\mathrm{T} 1,{ }^{0} \mathrm{C}$ & 1119,0 & 1089,0 & 1017,0 & 519,0 \\
$\alpha_{\mathrm{Pr}}\left(1600^{0} \mathrm{C}\right), \%$ & 83,3 & 85,5 & 90,2 & 95,9 \\
$\alpha_{\mathrm{Pr}}\left(1700^{0} \mathrm{C}\right), \%$ & 96,7 & 97,0 & 98,5 & 99,4 \\
\hline
\end{tabular}

\subsection{Kinetics of the Process}

Researches of kinetics of the phosphorus extraction in a gas phase at the chemical interaction of the ferrophosphorus, containing 26,4\% of phosphorus (FP), with the ferrosilicon of the grade FS 65, containing $63,8 \%$ of silicon (FS), were fulfilled in a temperature interval of $1873-2073 \mathrm{~K}$. It was preliminary established, that a FS/FP ratio $(\gamma)$ makes a significant impact on $\alpha_{P}$ (Table 4). In the further experiences $\gamma$ is equal 2,4.

Table 4. Influence of a FS/FP ratio on $\alpha_{P}$ at the melting of a charge during 120 minutes and $1973 \mathrm{~K}$

\begin{tabular}{cccccccc}
\hline$\gamma$ & 1,1 & 1,6 & 1,8 & 2,0 & 2,2 & 2,4 & 2,6 \\
\hline$\alpha_{\mathrm{P},} \%$ & 44,3 & 60,5 & 63,8 & 67,2 & 69,4 & 70,6 & 70,9 \\
\hline
\end{tabular}

Influence of the melting process's temperature and duration on $\alpha_{\mathrm{P}}$ is represented on the Figure 3.

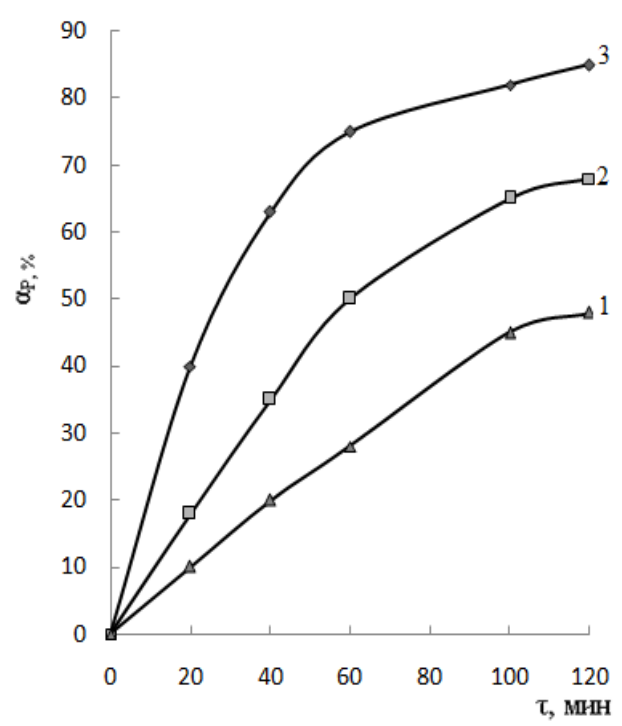

1-1873K, 2-1973K, 3-2073K

Figure 3. Influence of temperature and duration of the melting process on a degree of the gaseous phosphorus formation $\left(\alpha_{P}\right)$ in the system FP $-\gamma \mathrm{FS}$ at $\gamma=2,4$

The Figure 3 shows that a considerable $\alpha_{\mathrm{P}}(80-83 \%)$ can be reach at $2073 \mathrm{~K}$ within $100-120$ minutes. Thus the ferrosilicon is formed which contains $44,6 \%$ of $\mathrm{Si}, 48,8 \%$ of $\mathrm{Fe}, 1,7 \%$ of $\mathrm{P}, 1,9 \%$ of $\mathrm{Mn}$ and $3 \%$ of other (Figure 4).

Temperature influence on the parameters «n» and «k»» in the equation (6) is represented in the Figure 6. The dependence equations $n=f(T)$ and $k=f(T)$ look in the following way:

$$
\mathrm{n}=4,1554-0,00165^{*} \mathrm{~T},
$$




$$
\mathrm{k}=-3,5649+0,4729 * \ln \mathrm{T} .
$$
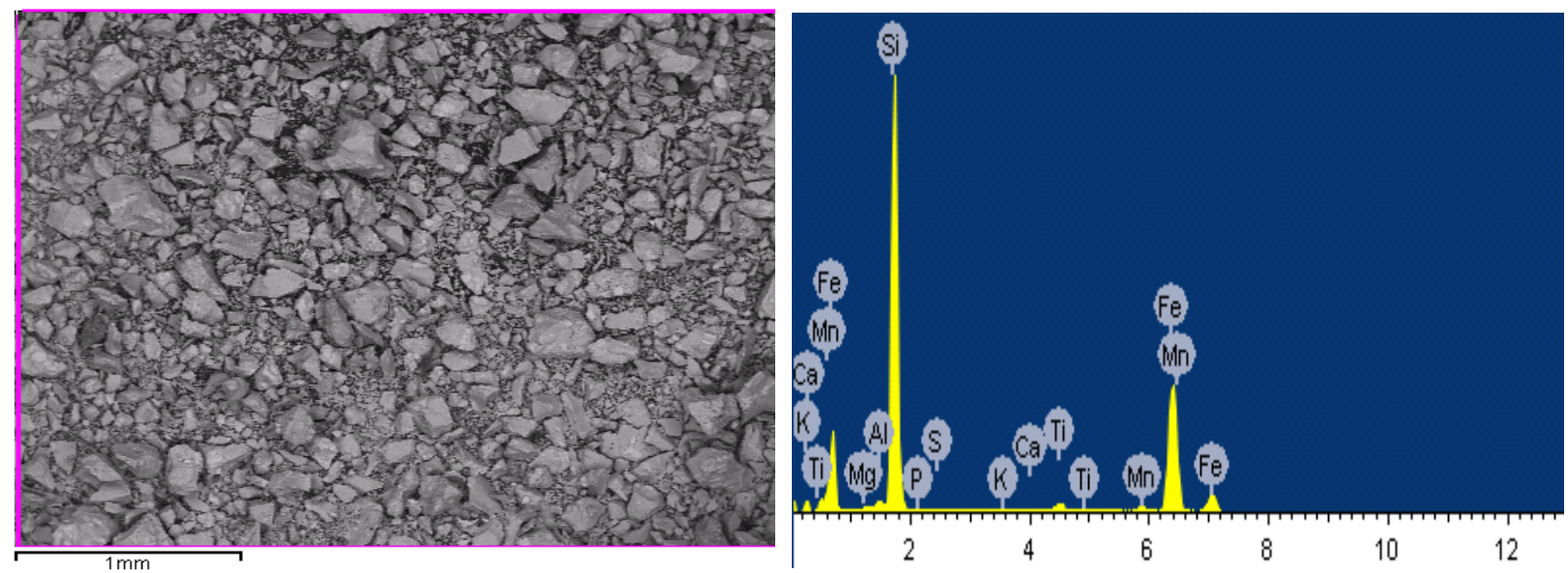

Figure 4. Electron microscopy of the ferrosilicon formed

Applicability of the equation (2) to the process of phosphorus extraction from the ferrophosphorus is shown on the Figure 6.

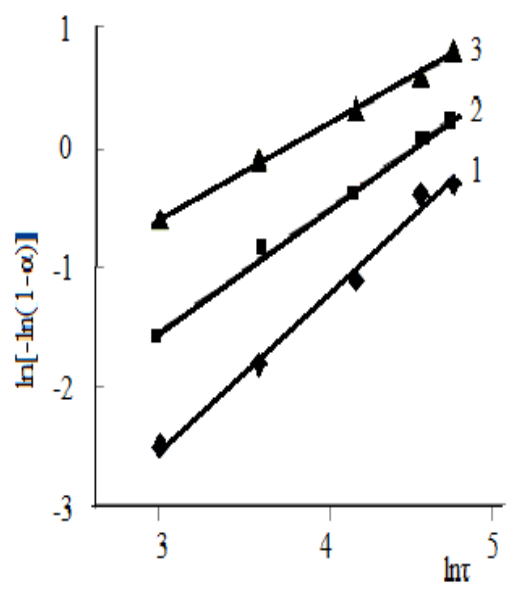

1 - 1873K, 2 - 1973K, 3 - 2073K

Figure 5. Dependence

$\ln [-\ln (1-\alpha)]=f(\ln \tau)$ at the extraction of phosphorus from the system FP - 2,4FS

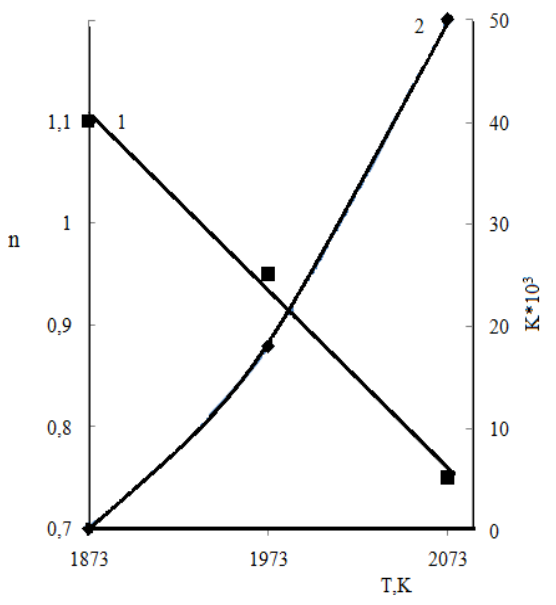

$1-\mathrm{n}=\mathrm{f}(\mathrm{T}), 2-\mathrm{k}=\mathrm{f}(\mathrm{T})$

Figure 6. Temperature influence on the parameters «n» and «k» of the equation (6) at the extraction of phosphorus from the system FP - 2,4FS

Substituting the equations $(17,18)$ in the equation (2) we have established the generalized dependence $\alpha_{\mathrm{P}}=\mathrm{f}(\mathrm{T}$, $\tau)$ :

$$
\alpha=1-\exp \left[(3,5649-0,4729) \cdot \tau^{\left(4,1514-16,5 \cdot 10^{-4} \cdot \mathrm{T}\right)}\right]
$$

After the differentiation of the equation (19) we have received the following expression for the phosphorus extraction rate $(\mathrm{V})$ :

$$
\left.V=\frac{\mathrm{d} \alpha}{d \tau}=\left(4,1554-16,5 \cdot 10^{-4} \cdot \mathrm{T}\right) \cdot(0,4729 \cdot \ln \mathrm{T}-3,5649)^{\frac{4,1554-16,5 \cdot 10^{-4} \cdot \mathrm{T}}{2}} \cdot[-\ln (1-\alpha))^{1-\frac{1}{4,1554-16,5 \cdot 10^{-4 . T} \mathrm{~T}}}\right] \cdot(1-\alpha)
$$

Using the equation (20), rates of the phosphorus extraction from the system FP $-2,4 \mathrm{FS}$ for $\alpha=0,2,0,3$ and 0,4 were determined (Table 5). 
Table 5. Influence of temperature and $\alpha_{\mathrm{P}}$ on the phosphorus extraction rate $(\mathrm{V})$ from the system FP $-2,4 \mathrm{FS}$

\begin{tabular}{cccc}
\hline Temperature, $K$ & \multicolumn{3}{c}{ V, parts of unity/minute } \\
\cline { 2 - 4 } & $\alpha=0,2$ & $\alpha=0,3$ & $\alpha=0,4$ \\
\hline 1873 & 0,00161 & 0,00146 & 0,00129 \\
1973 & 0,0129 & 0,0104 & 0,009 \\
2073 & 0,0177 & 0,0120 & 0,007 \\
\hline
\end{tabular}

The temperature effect on $\mathrm{V}$ in coordinates $\lg \mathrm{V}_{\mathrm{P}}=\mathrm{f}(1 / \mathrm{T})$ is represented in the Figure 7 . On the basis of this figure, using the equation (3), we detected that $\mathrm{E}_{\mathrm{ap}}$ depends from $\alpha_{\mathrm{P}}$, reducing at the $\alpha_{\mathrm{p}}$ decrease (Table 6).

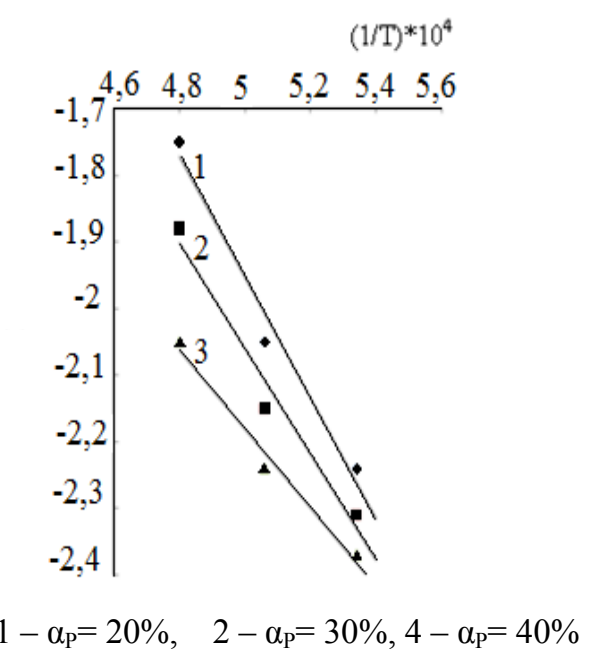

Figure 7. Dependence $\lg \mathrm{V}_{\mathrm{P}}=f(1 / \mathrm{T})$ at the extraction of phosphorus from the system $\mathrm{FP}-2,4 \mathrm{FS}$

Table 6. Influence of $\alpha_{\mathrm{P}}$ on an apparent activation energy of the phosphorus liberation from the system FP $2,4 \mathrm{FS}$

\begin{tabular}{cccc}
\hline$\alpha_{\mathrm{P}}, \%$ & 20 & 30 & 40 \\
\hline $\mathrm{E}_{\mathrm{ap}}, \mathrm{kJ} / \mathrm{mol}$ & 389 & 325 & 281 \\
\hline
\end{tabular}

Proceeding from the values $\mathrm{E}_{\mathrm{ap}}$ received follows, that the process of phosphorus extraction from ferrophosphorus in the presence of ferrosilicon FS 65 takes place in kinetic area, and the decrease of $E_{a p}$ at the increase of $\alpha_{\mathrm{p}}$ is a consequence of intensification of influence of mass exchange phenomena on the process. Nevertheless the process intensification demands the temperature increase.

\subsection{Determination of Optimum Parameters}

Independent variables are temperature (a coded kind $-\mathrm{X} 1$, a natural kind $-\mathrm{T},{ }^{0} \mathrm{C}$ ), duration of the melting (a coded kind $-\mathrm{X} 2$, a natural one $-\tau$, minutes) and a ratio of the ferrosilicon containing $63,8 \%$ of $\mathrm{Si}$ to the ferrophosphorus containing $26,4 \% \mathrm{P}$ (a coded kind $-\mathrm{X} 3$, a natural one $-\gamma$ ). A matrix of planning of experiments for the determination of influence of T, $\tau$ and $\gamma$ on degree of the phosphorus extraction in a gas phase ( $\alpha_{P}$, gas) is represented in the Table 7. On the basis of the experimental data (Table 7) the following adequate regression equation $\alpha_{\mathrm{P}(\mathrm{gas})}=\mathrm{f}(\mathrm{T}, \tau, \gamma)$ was received.

$$
\alpha_{P(\mathrm{gas})}=-3218.859+3.62 \cdot \mathrm{T}-32.781 \cdot \gamma+1.463 \cdot \tau+0.075 \cdot \mathrm{T} \cdot \gamma+0.00013 \cdot \mathrm{T} \cdot \tau+0.005 \cdot \tau \cdot \gamma-0.001 \cdot \mathrm{T}^{2}-21.736 \cdot \gamma^{2}-0.09 \cdot \tau^{2}
$$


Table 7. Matrix of planning of experiments on the processing of the ferrophosphorus containing $26,4 \%$ of phosphorus

\begin{tabular}{|c|c|c|c|c|c|c|c|c|}
\hline \multirow[t]{3}{*}{ № } & \multicolumn{6}{|c|}{ Variables } & \multicolumn{2}{|c|}{$\alpha_{\mathrm{P}_{\text {(gas) }},}, \%$} \\
\hline & \multicolumn{3}{|c|}{ A coded kind } & \multicolumn{3}{|c|}{ A natural kind } & & \\
\hline & $\mathrm{X} 1$ & $\mathrm{X} 2$ & $\mathrm{X} 3$ & $\mathrm{~T},{ }^{0} \mathrm{C}$ & $\tau, \min$ & $\gamma$ & experim. & calcul. \\
\hline 1 & 2 & 3 & 4 & 5 & 6 & 7 & 8 & 9 \\
\hline 1 & 1 & 1 & 1 & 1760 & 102 & 2,1 & 73.4 & 76.9 \\
\hline 2 & -1 & 1 & 1 & 1640 & 102 & 2,1 & 51.6 & 53.2 \\
\hline 3 & 1 & -1 & 1 & 1760 & 48 & 2,1 & 63.3 & 60 \\
\hline 4 & -1 & -1 & 1 & 1640 & 48 & 2,1 & 39.6 & 36.3 \\
\hline 5 & 1 & 1 & -1 & 1760 & 102 & 1,1 & 44.0 & 46.9 \\
\hline 6 & -1 & 1 & -1 & 1640 & 102 & 1,1 & 28.4 & 32.2 \\
\hline 7 & 1 & -1 & -1 & 1760 & 48 & 1,1 & 31.4 & 29.9 \\
\hline 8 & -1 & -1 & -1 & 1640 & 48 & 1,1 & 19.5 & 15.2 \\
\hline 9 & 1.6818 & 0 & 0 & 1800 & 75 & 1,6 & 66.4 & 65.2 \\
\hline 10 & -1.6818 & 0 & 0 & 1600 & 75 & 1,6 & 31.9 & 32.9 \\
\hline 11 & 0 & 1.6818 & 0 & 1700 & 120 & 1,6 & 62.2 & 54.9 \\
\hline 12 & 0 & -1.6818 & 0 & 1700 & 30 & 1,6 & 19.3 & 26.4 \\
\hline 13 & 0 & 0 & 1.6818 & 1700 & 75 & 2,4 & 65.4 & 66 \\
\hline 14 & 0 & 0 & -1.6818 & 1700 & 75 & 0,8 & 23.7 & 23 \\
\hline 15 & 0 & 0 & 0 & 1700 & 75 & 1,6 & 59.5 & 59.8 \\
\hline 16 & 0 & 0 & 0 & 1700 & 75 & 1,6 & 59.0 & 59.8 \\
\hline 17 & 0 & 0 & 0 & 1700 & 75 & 1,6 & 58.3 & 59.8 \\
\hline 18 & 0 & 0 & 0 & 1700 & 75 & 1,6 & 61.7 & 59.8 \\
\hline 19 & 0 & 0 & 0 & 1700 & 75 & 1,6 & 60.4 & 59.8 \\
\hline 20 & 0 & 0 & 0 & 1700 & 75 & 1,6 & 60.8 & 59.8 \\
\hline
\end{tabular}

On the basis of the equation (21) we constructed a response surface and its horizontal sections (Figures 8-11).

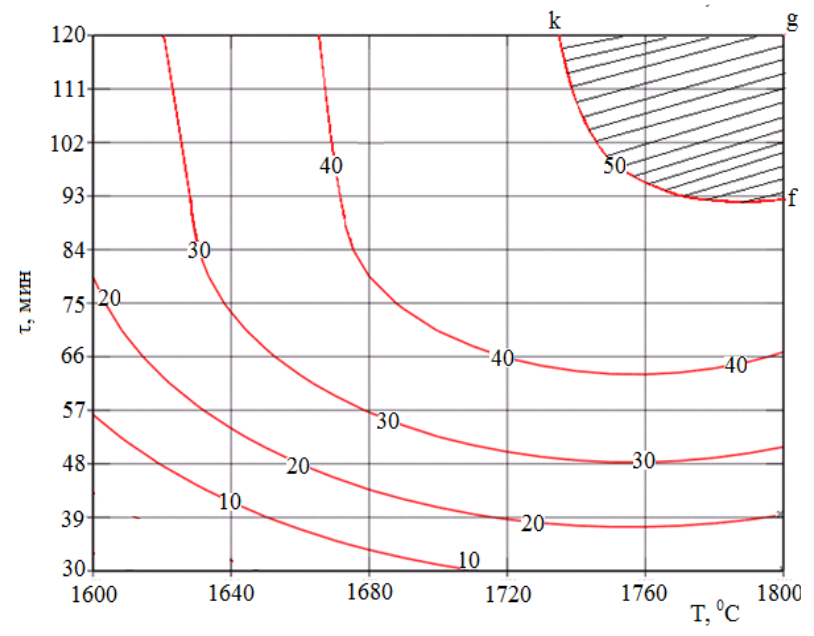

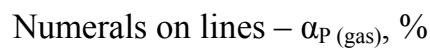

Figure 8. Horizontal sections of a response

surface $\left(\alpha_{\mathrm{P}(\mathrm{gas})}\right)$ at the melting of ferrophosphorus $(\mathrm{P}=$ $26,4 \%$ ) with ferrosilicon FS65, $\gamma=1,1$

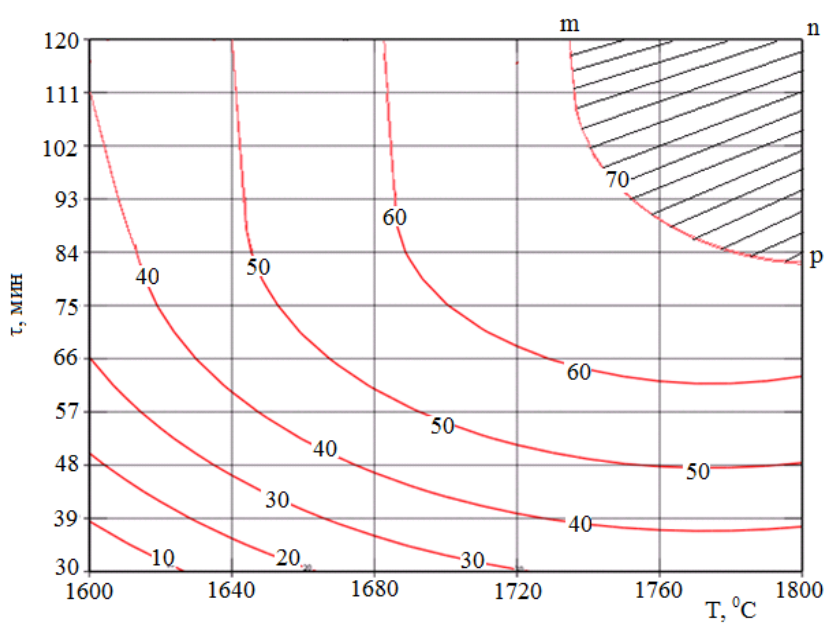

Numerals on lines $-\alpha_{\mathrm{P} \text { (gas) }}, \%$

Figure 9. Horizontal sections of a response surface $\left(\alpha_{\mathrm{P}(\mathrm{gas})}\right)$ at the melting of ferrophosphorus $(\mathrm{P}=$ $26,4 \%$ ) with ferrosilicon FS65, $\gamma=1,6$ 


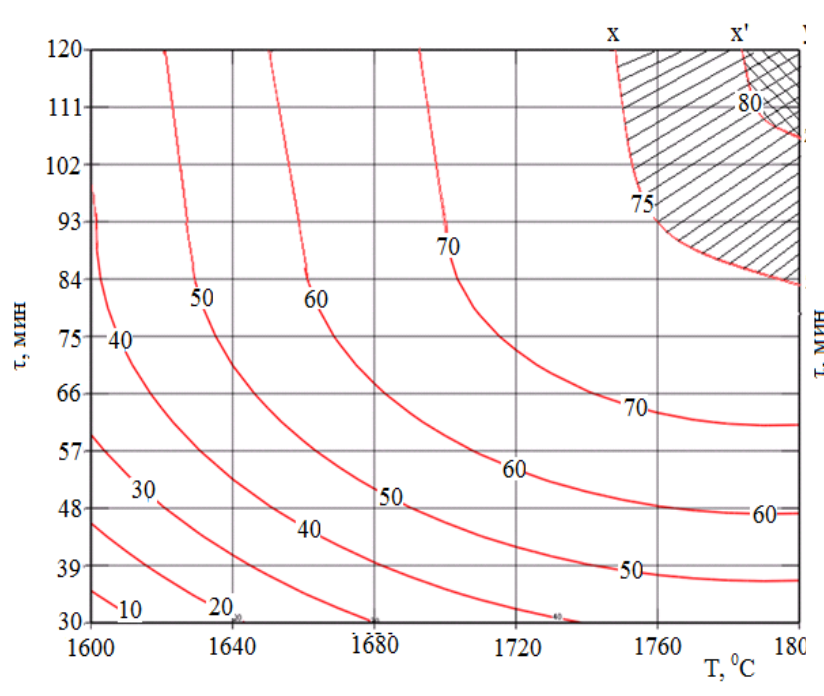

Numerals on lines $-\alpha_{\mathrm{P}(\mathrm{gas})}, \%$

Figure 10. Horizontal sections of a response surface $\left(\alpha_{\mathrm{P} \text { (gas) }}\right)$ at the melting of ferrophosphorus $(\mathrm{P}=$ $26,4 \%$ ) with ferrosilicon FS65, $\gamma=2,1$

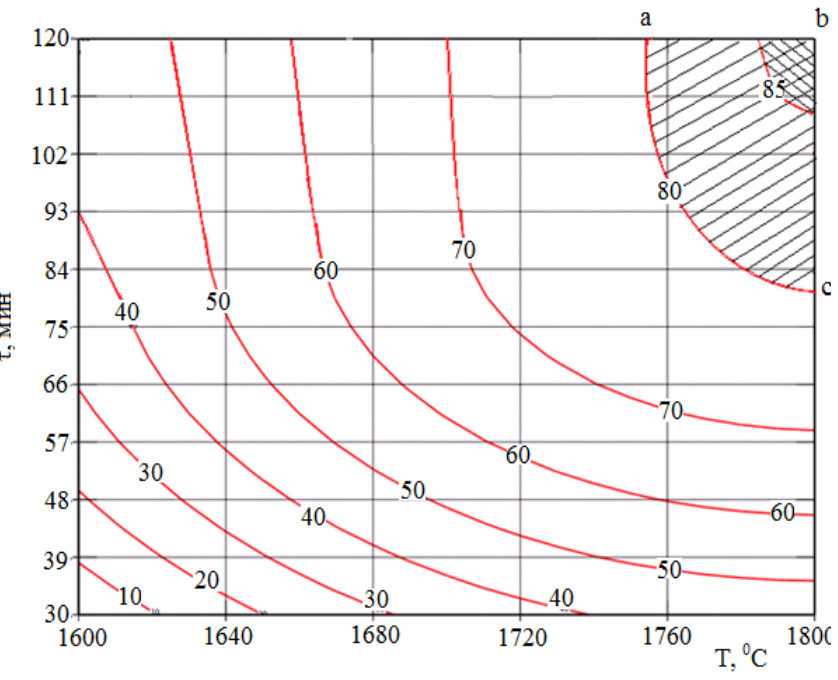

Numerals on lines $-\alpha_{\mathrm{P}(\mathrm{gas})}, \%$

Figure 11. Horizontal sections of a response surface $\left(\alpha_{\mathrm{P} \text { (gas) }}\right)$ at the melting of ferrophosphorus $(\mathrm{P}=$ $26,4 \%$ ) with ferrosilicon FS65, $\gamma=2,4$

As follows from the figures 8 and 9, the processing the ferrophosphorus, containing $26,4 \%$ of phosphorus, is noneffective at $\gamma=1,1$. In this case $\alpha_{\mathrm{p} \text { (gas) }}$ makes 50-54,8 \% (the area kgf, the Figure 8). At the increasing $\gamma$ to 1,6 , $\alpha_{\mathrm{p}(\mathrm{gas})}$ rises to $70-75 \%$ (the area mnp, the Figure 9). A high $(>80 \%) \alpha_{\mathrm{p}(\mathrm{gas})}$ can be reached at $\gamma=2,1$. However, the technological area $x^{\prime} y^{\prime} z$ ' (the Figure 10$)$ is very narrow $\left(\mathrm{T}=1790-1800^{\circ} \mathrm{C}\right.$ and $\left.\tau=108-120 \mathrm{~min}\right)$. At $\gamma=2,4$ $\alpha_{\mathrm{p}(\mathrm{gas})}$ reaches $80-86 \%$ (the area abc, the Figure $11, \mathrm{~T}=1755-1800^{\circ} \mathrm{C}$ and $\tau=84-120 \mathrm{~min}$ ). A ferroalloy formed in this case contains $43,02 \%$ of $\mathrm{Si} ; 39,11 \%$ of Fe; $2,57 \%$ of $\mathrm{Mn} ; 2,05 \%$ of $\mathrm{P}$, the Figure 12 . Such complex ferroalloy (an addition alloy) can be used for melting foundry irons of grades Л1-Л6 containing 0,08-0,1\% of P, $1,2-3,6 \%$ of Si, $0,5-1,0 \%$ of $\mathrm{Mn}(23)$, and also a heat-resistant grey cast iron (P - 0,05-1,0 \%, Si - 1-3 \%, Mn $0,25-1,0 \%$ ) and a malleable cast iron ( $\mathrm{P}-$ to $0,18 \%, \mathrm{Mn}-0,2-1,0 \%, \mathrm{Si}-1,1-1,6 \%)(24)$.

$\begin{array}{cc}\text { Element } & \text { Weight, \% } \\ \mathrm{Al} & 1,85 \\ \mathrm{Si} & 43,02 \\ \mathrm{P} & 9,05 \\ \mathrm{Ca} & 0,23 \\ \mathrm{Ti} & 0,56 \\ \mathrm{~V} & 0,22 \\ \mathrm{Cr} & 0,37 \\ \mathrm{Mn} & 2,57 \\ \mathrm{Fe} & 39,11\end{array}$

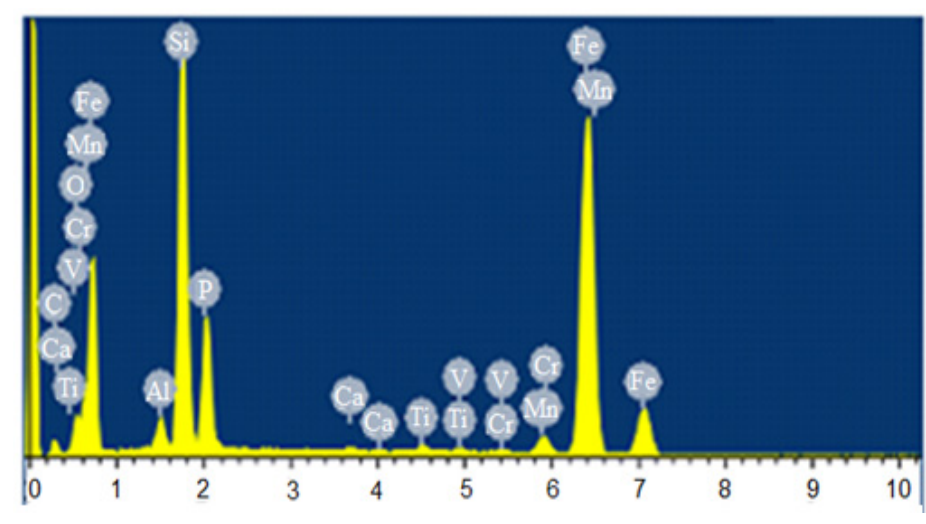

Figure 12. Electron microphotography and elemental composition of the ferroalloy produced at the melting the ferrophosphorus containing $26,4 \%$ of $\mathrm{P} ; \mathrm{T}=1800^{\circ} \mathrm{C}$; duration of the process is $100 \mathrm{~min} ; \gamma=2,4$

\section{Conclusions}

On the basis of the experiments' results in the field of theory and technology of the processing ferrophosphorus in the presence of iron silicates it is possible to draw the following conclusions:

- At low temperatures $\left(500-700^{\circ} \mathrm{C}\right)$ in the systems $\mathrm{Fe}_{3} \mathrm{P}-\mathrm{FeSi}_{2}, \mathrm{Fe}_{2} \mathrm{P}-\mathrm{FeSi}_{2}$ and $\mathrm{FeP}-\mathrm{FeSi}_{2}$ there is the 
saturation of iron phosphides by phosphorus and the formation of intermediate products $\mathrm{FeP}_{2}$ and $\mathrm{FeP}$, which react with the $\mathrm{FeSi}_{2}$ at increase of temperature and form a gaseous phosphorus (as $\mathrm{P}_{2}, \mathrm{P}_{4}$ ), i.e. the phosphorus liberation occurs through stages $\mathrm{Fe}_{3} \mathrm{P} \rightarrow \mathrm{Fe}_{2} \mathrm{P} \rightarrow \mathrm{FeP} \rightarrow \mathrm{FeP}_{2} \rightarrow\left(\mathrm{P}_{2}, \mathrm{P}_{4}\right)$.

- A temperature of initial and final stages of the phosphorus formation in systems iron phosphides $-\mathrm{FeSi}_{2}$ depends on an atomic content of phosphorus in a phosphide. At the increase of an atomic phosphorus content from 25 to $66,67 \%$, an initial temperature of the phosphorus formation decreases from $1110^{\circ} \mathrm{C}$ to $519^{\circ} \mathrm{C}$, and the transition of the phosphorus in a gaseous state increases. A temperature of the full conversion of all the phosphorus in a gaseous state decreases at the increase of a mole ratio $\mathrm{FeSi}_{2} / \mathrm{Fe}_{2} \mathrm{P}$. If a mole ratio $\mathrm{FeSi}_{2} / \mathrm{Fe}_{2} \mathrm{P}$ raises from 2 to 3,2, then a temperature of the full transition of the phosphorus in a gaseous state decreases from 1800 to $1400^{\circ} \mathrm{C}$.

- The phosphorus extraction from the ferrophosphorus in the presence of the ferrosilicon FS65 takes place in kinetic area, and the decrease of $\mathrm{E}_{\mathrm{ap}}$ in the process is a consequence of the growth of influence of mass exchange phenomena. For intensification of the process it is necessary to increase the process temperature.

- $\quad$ a high degree (80-86 \%) of the phosphorus extraction from the ferrophosphorus, containing $26,4 \%$ of $\mathrm{P}$, is observed at $1755-1800^{\circ} \mathrm{C}$ during $84-120$ minutes and a mole ratio ferrosilicon FS65:ferrophosphorus equal 2,4. A complex ferroalloy formed in this case (an addition alloy), containing 43,02 \% of Si; 2,57 \% of $\mathrm{Mn}$, $2,05 \%$ of $\mathrm{P}, 39,11 \%$ of $\mathrm{Fe}$, can be used at melting foundry irons, including heat-resistant and malleable cast irons.

\section{References}

Akhnazarova, S. A., \& Kapharov, B. V. (1978). Methods of experiment's optimization in the chemical industry. M.: Higher school, 319.

Alybaev, Zh. A. (1999). Development of scientific bases, working out and practical realization of a complex ferroalloys' industrial technology in chemistry and metallurgy: abstract of a doctoral thesis: 05.16.02; 05.17.01. - Almaty: Atamura.

Shreger, V., Laugenshleger, K., Bibrak, H., \& Shnavel, A. (1989). Chemistry: Reference book. Translation from German. M.: Chemistry. 648.

Ershov, V. A., \& Pimenov, S. D. (1996). Electrothermics of phosphorus.-St.Petersburg: Chemistry, 248.

Ershov, V. A. (1980). Ferroalloys in the chemical industry. Leningrad: Leningrad Technological Institute, 70.

Kazov, M. N., Kazova, R. A., \& Aljzhanov, T. M. (1989). Thermochemical preparation of raw material for the electrothermal production of phosphorus. Alma-Ata: Science, 216.

Konevsky, M. R. (2010). Ferrophosphorus as an alloying additive and a basis for new ways of production of chemical and metallurgical products. Collected papers of All-Russia scientific and technical conference “Electrothermics-2010”. St.Petersburg, 39.

Kunayev, A. M., \& Sukharnikov, Yu. I. (1972). Research of vacuum-thermal processing ferrophosphorus. Collected articles of the Institute of Metallurgy and Concentration of the Academy of Science of the Republic of Kazakhstan, 44, 30-34.

Teterevkov, I. A., Fomina, E. A., \& Shubayev, V. L. (1973). Methods of ferrophosphorus processing. Leningrad: RIFSCHC. 30.

Patent № 2373142(13) Russian Federation. A way of the processing a ferrophosphorus melt. Genkin M.V, Shvetsov S.V.; printed 20.11.2009.

Patent RU 2373142, C01B 25/08. Printed 20.11.2011.

Patent US 4014682, C21B3/04, C21B13/00. Printed 29.03.1977.

Patent CN1884052, C01B25/18, C01B25/00.Printed 27.12.2006.

Protopopov, A. V. (2002). Scientific principles and technologies of metallurgical processing of ferrophosphorus into special materials and products. Dissertation abstract: 05.16.03-Almaty. 35.

Pupyshov, A. A. (2007). Thermodynamic modelling thermochemical processes in spectral sources. Ekaterinburg, USTU-UPI.

Roine, A. (2002). Outokumpu HSC Chemistry for Windows. Chemical Reaction and Equilibrium software with Extensive Thermochemical Database. Pori: Outokumpu Research OY. 
Standard 390838120141-005-2010. Ferrophosphoruselectrothermal. Specifications. Limited partnership Kazphosphate, $2010 \mathrm{y}$.

State Standard 1415-93 (Interstate standard) Ferrosilicon. Technical requirements and delivery specification.

State Standard 4832-95 Foundry iron.

Ualieva, Z. U. (2008). Thermochemical processing a ferrophosphorus-soda charge. Academic bulletin. KrivoyRog, 21-22, 84-88.

Udalov, Yu. P. (2012). Using software packages of computer and geometrical thermodynamics in the designing technological processes of inorganic substances. St.Petersburg: St.Petersburg State Technological Institute (TU), 183.

Vanyukov, A. V., \& Zaytsev, V. Ya. (1973). Theory of pyrometallurgical processes. M.: Metallurgy, 504.

Yerofeev, B. V., \& Mickiewicz, N. I. (1961). In reactivity of solids. Ed. de Bocr. Elsevier. Amsterdam. 273.

\section{Copyrights}

Copyright for this article is retained by the author(s), with first publication rights granted to the journal.

This is an open-access article distributed under the terms and conditions of the Creative Commons Attribution license (http://creativecommons.org/licenses/by/3.0/). 